
\title{
.
}

\section{Rosiglitazone Promotes AQP2 Plasma Membrane Expression In Renal Cells Via a $\mathrm{Ca}^{2+}$-Dependent/CAMP-Independent Mechanism}

\author{
Giuseppe Procino Andrea Gerbino Serena Milano Maria Celeste Nicoletti \\ Lisa Mastrofrancesco Monica Carmosino Maria Svelto \\ Department of Biosciences, Biotechnologies and Biopharmaceutics, University of Bari, Bari, Italy
}

\section{Key Words}

Aquaporin $2 \cdot$ Vasopressin $•$ Thiazolidinediones $•$ Rosiglitazone $\cdot$ Calcium signaling $\bullet$ Transient receptor potential $\cdot$ Edema

\begin{abstract}
Background/Aims: Thiazolidinediones are highly beneficial in the treatment of type II diabetes. However, they are also associated with edema and increased risk of congestive heart failure. Several studies demonstrated that rosiglitazone (RGZ) increases the abundance of aquaporin-2 (AQP2) at the plasma membrane of renal cells. The aim of this study was to investigate whether RGZ might activate a transduction pathway facilitating AQP2 membrane accumulation in renal cells. Methods: We analyzed the effect of RGZ on renal AQP2 intracellular trafficking in MCD4 renal cells by confocal microscopy and apical surface biotinylation. Cytosolic $\mathrm{Ca}^{2+}$ dynamics were measured by a video-imaging approach in single cell. Transient Receptor Potential (TRP) channels expression was determined by RT-PCR. Results: We showed that in MCD4 cells, short-term exposure to RGZ dramatically increases the amount of apically expressed AQP2 independently on CAMP production, PKA activation and AQP2 phosphorylation. RGZ elicited a cytosolic $\mathrm{Ca}^{2+}$ transient due to $\mathrm{Ca}^{2+}$ influx prevented by ruthenium red, suggesting the involvement of TRP plasma membrane channels. We identified TRPV 6 as the possible candidate mediating this effect. Conclusions: Taken together these results provide a possible molecular mechanism explaining the increased AQP2 membrane expression under RGZ treatment: in renal cells RGZ elicits $\mathrm{Ca}^{2+}$ transients facilitating AQP2 exposure at the apical plasma membrane, thus increasing collecting duct water permeability. Importantly, this effect suggests an unexplored application of RGZ in the treatment of pathological states characterized by impaired AQP2 trafficking at the plasma membrane.
\end{abstract}

Copyright (c) 2015 S. Karger AG, Basel

Dr. Giuseppe Procino

Assistant Professor of Physiology

KARGER 125
Department of Biosciences, Biotechnologies and Biopharmaceutics Via Amendola 165/A 70126, Bari (Italy)

Tel. +39-080-5443414, Fax +39-080-5443388, E-Mail giuseppe.procino@uniba.it 


\section{Introduction}

Administration of peroxisomal proliferator-activated receptor sub- type $\gamma$ (PPAR- $\gamma$ ) agonists, thiazolidinediones (TZDs, rosiglitazone and pioglitazone), produces beneficial effects on type 2 diabetes by increasing insulin sensitivity, decreasing blood pressure and inhibiting inflammation [1-5]. Unfortunately, one side effect of these drugs is the tendency, for rosiglitazone (RGZ) in particular, to lead to fluid retention [6] causing edema and congestive heart failure in some patients $[7,8]$, by a not fully understood mechanism, likely involving increased salt and water reabsorption in the kidney. PPAR- $\gamma$ belong to the PPAR family of nuclear receptors, is expressed in various organs and binds to PPAR responsive elements (PPRE) to regulate a number of target genes [9]. Within the kidney, PPAR- $\gamma$ are expressed in the collecting duct (CD) [10-12]. This localization suggests that PPAR- $\gamma$ may be physiologically involved in the fine regulation of electrolytes and water excretion in the distal nephron.

Many works tried to demonstrate an involvement of RGZ in modulating the expression of the main $\mathrm{Na}^{+}$transporters and water channels in the kidney. Song and co-workers demonstrated in rats that RGZ increased the whole kidney protein abundance of the $\alpha-1$ subunit of $\mathrm{Na}^{+}-\mathrm{K}^{+}$-ATPase, the bumetanide-sensitive $\mathrm{Na}^{+}-\mathrm{K}^{+}-2 \mathrm{Cl}^{-}$cotransporter (NKCC2), the sodium hydrogen exchanger (NHE3), the aquaporins 2 and 3 water channels (AQP2, AQP3) and the endothelial nitric-oxide synthase (NOS) [13]. Confirmation that TZDs stimulate $\mathrm{Na}^{+}$and water reabsorption in the CD was provided by Zhang et al., who demonstrated that CD-specific deletion of PPAR- $\gamma$ prevented the TZDs-induced fluid retention [14]. However, Vallon et al. demonstrated that the TZD-induced fluid retention is independent of ENaC activity [15].

The limiting barrier for water reabsorption in the $\mathrm{CD}$ is represented by the availability of the water channel AQP2 at the apical plasma membrane of CD epithelial cells [16-18]. The physiological stimulus increasing exocytosis of AQP2 storage vesicles at the apical plasma membrane is the systemic release of the antidiuretic hormone arginine-vasopressin (AVP) [19]. However, in the last decade, a number of vasopressin-independent mechanisms of AQP2 trafficking have been identified, leading to AQP2 plasma membrane accumulation in renal cells at short-term [20-22].

In RGZ-treated rats AQP2 total protein levels and the plasma membrane-associated fraction were upregulated at day three of treatment, likely contributing to cause water retention, but downregulated after five days as an attempt to re-establish water balance [23]. Increased expression of AQP2 at the plasma membrane suggests that RGZ might activate a short-term intracellular mechanism responsible for increased AQP2 apical expression. In the present work we investigated the effect of RGZ treatment on short-term AQP2 trafficking in kidney collecting duct MCD4 cells [24]. We found that RGZ induces a dose-dependent translocation of AQP2 exocytic vesicles to the apical plasma membrane. This event is independent on intracellular cAMP elevation and AQP2 phosphorylation but concomitant with $\mathrm{Ca}^{2+}$ influx likely mediated by RGZ-induced TRPV6 channels activation.

\section{Materials and Methods}

Antibodies And Reagents

Ruthenium Red (RR), cyclopiazonic acid (CPA), H-89 dihydrochloride hydrate, adenosine triphosphate (ATP), 3-isobutyl-1-methylxanthine (IBMX) and RN-1734 were purchased from Sigma (www.sigmaaldrich. com). Fura-2-AM was obtained from Molecular Probes (www.lifetechnologies.com ). Rosiglitazone maleate was purchased from Vinci-Biochem (www.vincibiochem.it). Silencer® Select Pre-Designed siRNA against mus musculus TRPV6, and relative negative control, (Cat. \#4390771 and \#4390843) were from Life technologies (www.lifetechnologies.com).

Rabbit affinity-purified polyclonal antibody against human AQP2 was previously described [25]. Rabbit affinity-purified polyclonal antibody against rat phosphorylated AQP2 at serine 256 were produced 
as previously described [26]. EZ-link Sulfo-NHS-biotin and Streptavidin Agarose Resin were from Thermo Scientific (www.piercenet.com).

\section{Cell culture}

MCD4 cells, a clone of M-1 cells [27] stably transfected with human-AQP2, were cultured as elsewhere described [24, 28], grown on $0.4 \mu \mathrm{m}$ pore size cell culture insert (www.corning.com ) and used two days after full confluence. Twenty-four hours before experiment cells were transferred to Opti-MEM $®$ reduced serum medium (www.lifetechnologies.com ) and treated with the cyclooxigenase inhibitor indomethacin 50 $\mu \mathrm{M}$ overnight in the culture medium to prevent the increase in basal cAMP concentration due to autocrine/ paracrine stimulation of P2-purinergic receptors [29, 30] as previously reported [24]. Confluence and polarization of cells was assessed by staining with the tight junctions marker ZO-1 (not shown).

\section{Immunofluorescence}

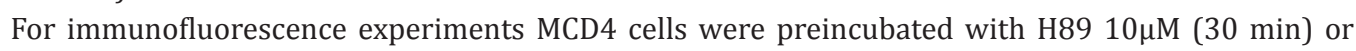
Ruthenium Red $10 \mu \mathrm{M}$ (5 min) or transfected with siRNAs (48h). Following, cells were stimulated with FK $100 \mu \mathrm{M}$ (30 min) or $50 \mu \mathrm{M}$ RGZ (30 min). Untreated cells were considered as control condition (ctr). Cell monolayers were then fixed with ice-cold methanol for $5 \mathrm{~min}$ and washed twice for $5 \mathrm{~min}$ in PBS. Cells were blocked with 1\% BSA in PBS, then the primary antibody (anti AQP2 affinity purified) was diluted in PBS-BSA and incubated for $2 \mathrm{~h}$ at RT. Bound antibody was detected with Alexa Fluor 488 conjugated donkey anti-rabbit IgG antibodies (www.lifetechnologies.com). All incubations were performed from both sides of the filters. Filters were excised from the support, mounted on microscope slides and viewed with a Leica TCS-SP2 confocal microscope (www.leica-microsystems.com).

\section{Apical surface biotinylation}

MCD4 cells were incubated in the presence of $100 \mu \mathrm{M}$ FK or $20 / 50 \mu \mathrm{M}$ rosiglitazone for $20 \mathrm{~min}$ in the culture medium at $37^{\circ} \mathrm{C}$. Biotinylation was performed as elsewhere described [24].

Briefly, filters were washed twice in ice-cold EBS buffer (10 mM triethanolamine pH 9.0,150 mM NaCl, $1 \mathrm{mM} \mathrm{MgCl}, 0.1 \mathrm{mM} \mathrm{CaCl}_{2}$ ), and the apical side was incubated with biotin $2.5 \mathrm{mg} / \mathrm{ml}$ EZ-link Sulfo NHSbiotin in EBS buffer on ice for $30 \mathrm{~min}$. Filters were washed twice in ice-cold PBS-CM and unbound biotin was quenched for $10 \mathrm{~min}$ in quenching buffer $\left(50 \mathrm{mM} \mathrm{NH}_{4} \mathrm{Cl}\right.$ in PBS-CM) on ice.

Cells were scraped from filters in $500 \mu$ l of lysis buffer (20 mM Tris- $\mathrm{HCl} \mathrm{pH} \mathrm{8.0,150} \mathrm{mM} \mathrm{NaCl,} 5 \mathrm{mM}$ EDTA, 1\% Triton X- 100, 0.2\% BSA, 1 mM PMSF, protease inhibitors cocktail), lysates were sonicated for 30 seconds and incubated at $37^{\circ} \mathrm{C}$ for $20 \mathrm{~min}$.

Insoluble material was pelleted at $13,000 \mathrm{~g}$ for $10 \mathrm{~min}$ and biotinylated proteins in the supernatants were precipitated for 16 hours with $50 \mu \mathrm{l}$ of streptavidin-agarose bead suspension under rotation at $4^{\circ} \mathrm{C}$. Beads from each condition were washed three times in complete lysis buffer and three times in lysis buffer without BSA. Biotinylated proteins were extracted in $30 \mu \mathrm{l}$ of NuPAGE LDS Sample buffer (www. lifetechnologies.com ) with $100 \mathrm{mM}$ DTT, heated at $95^{\circ} \mathrm{C}$ for $10 \mathrm{~min}$.

\section{Protein separation and Immunoblotting}

Biotinylated proteins were resolved on 4-12\% NuPAGE gels and electrophoretically transferred to Immobilon-P PVDF membrane (www.emdmillipore.com ) for Western blot analysis.

After blocking with $3 \%$ bovine serum albumin in TRIS buffer saline-tween 20, blots were incubated overnight at $4{ }^{\circ} \mathrm{C}$ with rabbit anti-AQP2 and anti-p ${ }^{256} \mathrm{AQP} 2(1 \mu \mathrm{g} / \mathrm{ml}$, affinity-purified Ab). Membranes were washed and incubated with horseradish peroxidase-conjugated anti rabbit IgG. Reactive proteins were revealed with an enhanced chemiluminescent detection system (SuperSignal West Pico Chemiluminescent Substrate www.piercenet.com) and chemiluminescence was detected with Chemidoc XRS detection system equipped with Image Lab Software for image acquisition (www.bio-rad.com).

The quantification of protein bands was performed by determination of the relative optical density using ImageJ software (National Institutes of Health, Bethesda, MD).

For statistical analysis, GraphPad Prism software (version 5.00, GraphPad Software, San Diego, California, USA) was used. Significant differences between means were tested by one-way analysis of variance (ANOVA) with Newman-Keuls's post-test. Significance was accepted for P values $<0.05$.

\section{KARGER}


Intracellular $\mathrm{Ca}^{2+}$ measurements

For intracellular $\mathrm{Ca}^{2+}$ measurements, cells were seeded on $\emptyset 40 \mathrm{~mm}$ glass coverslips. MCD 4 cells were loaded with 5-7 $\mu \mathrm{M}$ Fura-2AM for $30 \mathrm{~min}$ at $37^{\circ} \mathrm{C}$ in DMEM. Ringer's Solution was used to perfuse cells during the experiment containing $140 \mathrm{mM} \mathrm{NaCl}, 5 \mathrm{mM} \mathrm{KCl}, 1 \mathrm{mM} \mathrm{MgCl}{ }_{2}, 10 \mathrm{mM}$ Hepes, $5 \mathrm{mM}$ Glucose, 1.0 $\mathrm{mM} \mathrm{CaCl}{ }_{2}, \mathrm{pH}$ 7.4. MCD4 cells were stimulated with a variety of drugs as described in the results, including adenosine triphosphate, Cyclopiazonic acid, Ruthenium red, RN-1734 and rosiglitazone. For fluorescence measurements, the coverslips with dye-loaded cells were mounted in a perfusion chamber (FCS2 Closed Chamber System, BIOPTECHS, Butler, U.S.A.) and measurements were performed using an inverted microscope (Nikon Eclipse TE2000-S microscope) equipped for single cell fluorescence measurements and imaging analysis. The sample was illuminated through a $40 \mathrm{X}$ oil immersion objective $(\mathrm{NA}=1.30)$. The Fura2AM loaded sample was excited at 340 and $380 \mathrm{~nm}$ every 5 seconds. Emitted fluorescence was passed through a dichroic mirror, filtered at $510 \mathrm{~nm}$ (Omega Optical, Brattleboro, VT, USA) and captured by a cooled CCD camera (CoolSNAP HQ, Photometrics). Fluorescence measurements were carried out using Metafluor software (Molecular Devices, MDS Analytical Technologies, Toronto, Canada). Results are presented as the ratio of the fluorescence signal obtained upon excitation at $340 / 380 \mathrm{~nm}$. The bar graphs show the averaged rate of fluorescence ratio changes with respect to those elicited by ATP used in each experiment as internal control. Data from 20 to 40 cells were summarized in a single run, and at least three independent experiments were conducted.

Paired data were assessed for statistical significance using the Student's $t$ test. Data are expressed as means \pm SEM with $\mathrm{N}$ equal to the number of experiments. $\mathrm{P}<0.05$ was considered statistically significant for Fura-2 ratio imaging experiments.

\section{Intracellular cAMP measurements}

Intracellular cAMP level was imaged in single cells using Epac H96 [CFP(d)Del-EPAC(dDEPCD)cp173Venus(d)-Venus(d)] or Epac H90 [CFP(nd)-EPAC(2DEP/CD)-cp173Venus(d)] [31]. These reporters (kindly provided by Kees Jalink, Netherlands Cancer Institute) are soluble monomeric constructs that rely on conformation-dependent FRET between YFP- and CFP-labeled fragments of the Epac protein. Wildtype MCD4 cells were transiently transfected with Epac H90 or Epac H96 using the Lipofectamine 2000 transfection reagent (www.lifetechnologies.com). Real-time digital imaging measurements of the 480 $\mathrm{nm}$-to-535 nm FRET emission ratio (reflecting the degree of Epac conformational changes and, hence, intracellular cAMP levels) were carried out on subconfluent cells using a Metafluor-based imaging set-up and the perfusion apparatus described above. Data from 3 to 5 cells were summarized in a single run, and at least four independent experiments were conducted. Paired data were assessed for statistical significance using the Student's $t$ test. Data are expressed as means \pm SEM with $N$ equal to the number of experiments $P$ $<0.05$ was considered statistically significant also for cAMP FRET experiments.

\section{RNA isolation and RT-PCR}

Total RNA was extracted from confluent MCD4 cells and adult mouse kidney by the TRIzol extraction method (TRIzol reagent, www.lifetechnologies.com) and then was reverse transcribed into cDNA using Super-Script ${ }^{\circledR}$ VILO $^{\text {TM }}$ cDNA Synthesis Kit (www.lifetechnologies.com). PCR amplifications were performed using Taq DNA Polymerase recombinant (www.lifetechnologies.com) according to the following program:

$\left(94^{\circ} \mathrm{C}, 5 \mathrm{~min}\right) \times 1$ cycle;

$\left(94^{\circ} \mathrm{C}, 45 \mathrm{~s} ; 52^{\circ} \mathrm{C}, 30 \mathrm{~s} ; 72^{\circ} \mathrm{C}, 1 \mathrm{~min}\right) \times 30$ cycles;

$\left(72^{\circ} \mathrm{C}, 10 \mathrm{~min}\right) \times 1$ cycle.

The primers (Table 1) were designed on the basis of the mus musculus TRP channels nucleotide sequences available in the GenBank database (web site: http://www.ncbi.nlm.nih.gov/nuccore).

The primers pairs were chosen to hybridize with complementary DNA sequences derived from different exons, thereby excluding those amplimers arising from genomic DNA contamination. The specificity of the cDNAs amplified by RT-PCR was confirmed by cloning and sequencing the PCR fragment (data not shown).

A positive control was performed by using primers specific for mouse $\beta$-actin complementary DNA (not shown).

The PCR products were separated on a $1 \%$ agarose gel and were visualized with ethidium bromide. 
Table 1. Primers used for RT-PCR of TRP channels

\begin{tabular}{|c|c|c|}
\hline TRP Channel & Sequence of primers $\left(5^{\prime}-3^{\prime}\right)$ & Expected Product Size (bp) \\
\hline \multirow[t]{2}{*}{ TRPP2 } & TCTGGAAGTTCACCGAAGGC & 769 \\
\hline & AGCCССТCTGCATTTGACAT & \\
\hline \multirow[t]{2}{*}{ TRPV4 } & TCCTGAGGCCGAGAAGTACA & 869 \\
\hline & ATCCTTGGGCTGGAAGAAGC & \\
\hline \multirow[t]{2}{*}{ TRPV5 } & GTACGTGCAAGAAGACATGGG & 597 \\
\hline & AGTACTGTATTTCCCAGGGGT & \\
\hline \multirow[t]{2}{*}{ TRPV6 } & GCAGAAGAGGATCTGGGAATCA & 508 \\
\hline & TTTGTTGGGCTGCAGGATGA & \\
\hline \multirow[t]{2}{*}{ TRPM3 } & TAAGTTCCAAGCAGGGGTCC & 976 \\
\hline & CСАСТСССАТСACAGACCAC & \\
\hline \multirow[t]{2}{*}{ TRPC3 } & CCGCTATGTCCACCAAGGTC & 972 \\
\hline & TCCTGTAGTCATTCTTGAACTCC & \\
\hline \multirow[t]{2}{*}{ TRPC6 } & СTCTCTAAAGGCTGCCCCTG & 604 \\
\hline & CCGCGTCCCATCTTCATCAT & \\
\hline
\end{tabular}

$R N A i$

MCD4 cells were transfected with Lipofectamine 2000 reagent (www.lifetechnologies.com) alone (mock control), or with 100nM siRNA targeting TRPV6 or control siRNA, in serum-free Opti-MEM. Cells were then subjected to total RNA extraction and RT-PCR, immunofluorescence or intracellular $\mathrm{Ca}^{2+}$ measurements.

To assess the degree of TRPV6 silencing, a non-saturating RT-PCR protocol for TRPV6 and $\beta$-actin was performed using specific primer pairs as described above. The intensity of each PCR band was quantified using ImageJ software, version 1.6 (Research Services Branch, National Institute of Mental Health, Bethesda, MD). Peaks representing each band were obtained using the ImageJ Gel Analysis tool, and measures of the area under each peak were used for calculating the ratio of TRPV6 over $\beta$-actin.

\section{Results}

RGZ increases AQP2 apical expression with a cAMP/PKA-independent mechanism

The study was performed on MCD4 cells [24], a clone of M-1 cells [27] stably transfected with human-AQP2. We incubated polarized renal MCD4 cells, grown on porous cell culture insert, with different concentrations of $\operatorname{RGZ}(5,10,20,50,100 \mu \mathrm{M})$ in the culture medium for $20 \mathrm{~min}$ to investigate the possible effect of this drug on AQP2 subcellular localization. Fig. 1A reports the confocal analysis of AQP2 localization in resting cells (Ctr), after forskolin stimulation (FK) and after treatment with RGZ $50 \mu \mathrm{M}$ for $20 \mathrm{~min}$. All conditions were analyzed in the presence or in the absence of $10 \mu \mathrm{M}$ H89 a selective PKA inhibitor. RGZ treatment resulted in AQP2 redistribution from intracellular storage vesicles to the apical plasma membrane of renal cells. This effect was observed both in a xy confocal plan, passing through the cell apical membrane (upper panel), and in the xz confocal plan. The effect of RGZ on AQP2 translocation was comparable to that obtained by maximal FK stimulation (Fig. $1 \mathrm{~A}, \mathrm{FK})$. Interestingly, $10 \mu \mathrm{M}$ H89 completely prevented FK-induced AQP2 plasma membrane accumulation (Fig. $1 \mathrm{FK}+\mathrm{H} 89$ ) but did not prevent the same RGZ-induced effect on AQP2 trafficking (Fig. 1A, RGZ+H89).

The effect of RGZ on AQP2 translocation was dose-dependent, as lower doses $(5,10$, $20 \mu \mathrm{M}$ ) produced a smaller effect compared to that obtained at $50 \mu \mathrm{M}$ (not shown).

We also measured the possible effect of RGZ on cAMP levels with the Epac-based FRET sensor H90. Results, reported in Fig. 1B, showed that RGZ $50 \mu \mathrm{M}$ did not induce significant changes in cAMP levels when compared with submaximal doses of the cAMPincreasing drugs forskolin and IBMX ( 5 and $100 \mu \mathrm{M}$, respectively) used as internal control. In addition, we repeated RGZ stimulation in the continuous presence of $100 \mu \mathrm{M}$ IBMX to prevent compartmentalization of cAMP and again, we were not able to record any significant increase in cAMP levels in H90-transfected MCD4 cells (Fig. 1C).

Furthermore, to exclude that undetected cAMP signaling could still activate PKA and phosphorylate AQP2, a key event promoting AQP2 exocytosis at the apical plasma membrane in renal cells, we investigated whether RGZ could increase AQP2 phosphorylation that site. We used a previously characterized phospho-specific antibody against $\mathrm{p}^{256} \mathrm{AQP} 2$ [26]. 


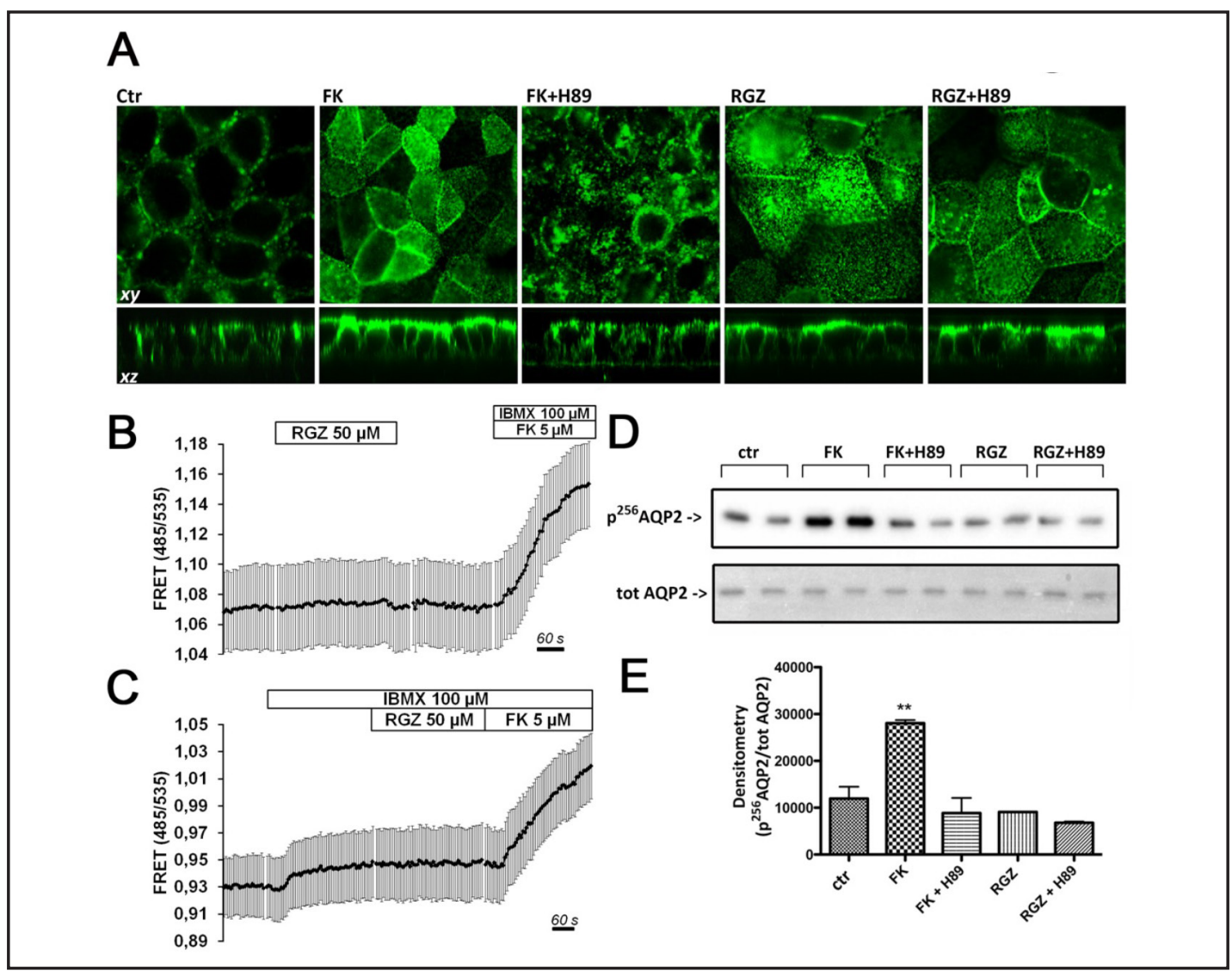

Fig. 1. RGZ increases apical plasma membrane expression of AQP2 in MCD4 cells by a cAMP/PKA-independent mechanism. (A) Immunofluorescence analysis of AQP2 subcellular localization in MCD4 renal cells in resting condition (Ctr), after $100 \mu \mathrm{M}$ FK stimulation, and after incubation with rosiglitazone $50 \mu \mathrm{M}$ in the absence (RGZ) or in the presence of the PKA inhibitor H89 (RGZ+H89). AQP2 immunostaining was visualized in the xy apical confocal plan (upper panels) and in the xz confocal plan (lower panels). Compared to Ctr conditions, FK and RGZ redistributed AQP2 staining to the apical plasma membrane. H89 prevented the FKbut not the RGZ-induced effect on AQP2 membrane accumulation indicating that the latter was independent on PKA activation. Pictures are representative of at least three independent experiments giving the same results. (B) Response of Epac H90-transfected MCD4 cells to rosiglitazone (RGZ, $50 \mu \mathrm{M}$ ) compared with the cAMP-elevating drugs forskolin (FK) and IBMX (5 and $100 \mu \mathrm{M}$, respectively) used as internal control. The data plotted are averaged from all the cells acquired for each experiment $(n=4)$. Data are expressed as mean (squares) \pm SE (vertical bars). (C) Response of Epac H90-transfected MCD4 cells to rosiglitazone (RGZ, 50 $\mu \mathrm{M}$ ) in the continuous presence of $100 \mu \mathrm{M}$ IBMX) compared with the cAMP-elevating drugs forskolin (FK) and IBMX (5 and $100 \mu \mathrm{M}$, respectively) used as internal control. The data plotted are averaged from all the cells acquired for each experiment $(n=3)$. Data are expressed as mean (squares) \pm SE (vertical bars). (D) Cells were treated as in (A) and cell lysates subjected to immunoblotting analysis of the phosphorylated AQP2 at ser256 ( $\mathrm{p}^{256} \mathrm{AQP} 2$ ) by a phospho-specific antibody. (E) Band densities were normalized for the total content of AQP2 (tot AQP2) and expressed means \pm SE of 3 independent experiments. ${ }^{* *} \mathrm{P}<0.01$ relative to ctr by 1way Anova/Newman-Keuls Multiple comparison test.

Fig. 1D reports the immunoblotting analysis performed on lysates of MCD4 cells treated in the same experimental conditions reported above. The signal from total AQP2 was used to normalize that of $\mathrm{p}^{256} \mathrm{AQP} 2$. The densitometry analysis (Fig. 1E) indicated that FK but not RGZ was able to induce a significant increase of $\mathrm{p}^{256} \mathrm{AQP} 2$ that was significantly inhibited by pretreatment with $\mathrm{H} 89$.

To semi-quantify the effect of RGZ on AQP2 apical expression, we performed apical surface biotinylation experiment on polarized MCD4 cells in the presence of RGZ as reported

\section{KARGER}


A

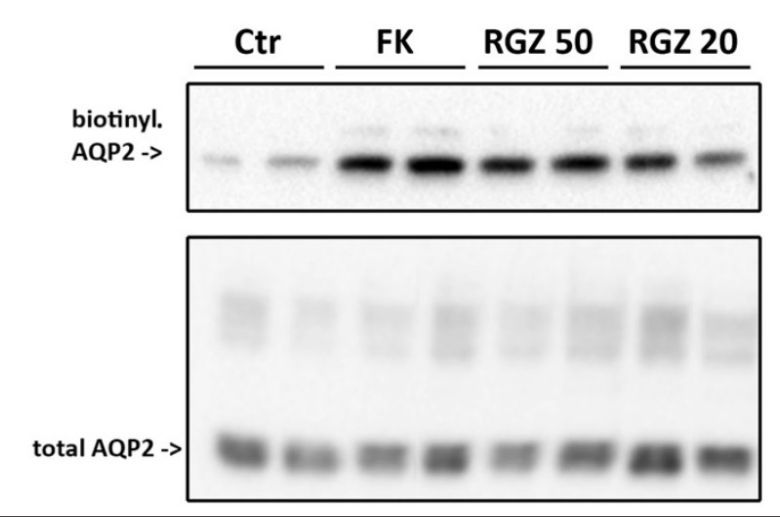

B

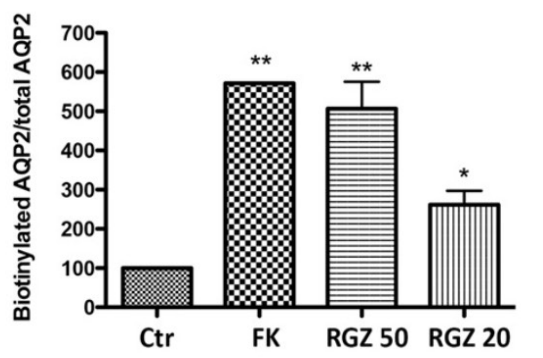

Fig. 2. Semiquantitation of the effect of RGZ on AQP2 expression at the apical plasma membrane of MCD4 cells. MDC4 cells were either left untreated (Ctr) or stimulated with $100 \mu \mathrm{M}$ FK or incubated with rosiglitazone (RGZ) 20 or $50 \mu \mathrm{M}$ for $30 \mathrm{~min}$. (A) Cells were then subjected to apical surface biotinylation experiments. Biotinylated proteins were recovered and immunoblotted for AQP2. (B) Densitometric analysis of the 29-kDa biotinylated AQP2 band was performed after normalization for the total amount of AQP2 for each experimental condition. Values are expressed as means \pm SE of 3 independent experiments. The amount of biotinylated AQP2 obtained in resting cells (Ctr) was set as $100 \%{ }^{* *} P<0.01$; $^{*} \mathrm{P}<0.05$ relative to Ctr by 1way Anova/Newman-Keuls Multiple comparison test.

in Fig. 2A and the densitometry analysis in Fig. 2B. In resting cells (ctr) a small amount of AQP2 was exposed to Sulfo NHS-biotin incubated in the extracellular medium at the apical side. As previously reported in this cell line [24], maximal FK stimulation promoted a 5-fold increase in the plasma membrane-expressed AQP2 (Fig. 2, FK). RGZ 50 $\mathrm{M}$ dramatically increased apical AQP2 expression and the effect was dose-dependent, as lower concentration (RGZ $20 \mu \mathrm{M}$ ) elicited a smaller effect. The maximal effect induced by RGZ was comparable to that elicited by maximal FK stimulation. Fig. 2B reported the statistical analysis of biotinylated AQP2 normalized for total AQP2 expressed in each experimental condition.

\section{RGZ increases intracellular [ $\left.\mathrm{Ca}^{2+}\right]$ as measured in Fura-2-loaded MCD4 cells}

We next investigated whether the effect of RGZ on AQP2 plasma membrane accumulation was mediated by perturbation of the intracellular $\mathrm{Ca}^{2+}$ homeostasis in MCD4 cells. The results shown in Fig. 3 indicate that in the presence of $1 \mathrm{mM}$ extracellular $\mathrm{Ca}^{2+}$ in the perfusion solution, 20 min exposure to $50 \mu \mathrm{M}$ RGZ elicited a cytosolic $\mathrm{Ca}^{2+}$ increase significantly larger than that produced by the $\mathrm{Ca}^{2+}$-mobilizing agonist ATP $(100 \mu \mathrm{M})$ in the same cells (Fig. 3A). Similar results were obtained with $100 \mu \mathrm{M}$ RGZ and increases of intracellular $\left[\mathrm{Ca}^{2+}\right]$ could be detected with RGZ concentrations as low as $20 \mu \mathrm{M}$ (Fig. 3B). In addition, the response to 50 $\mu$ M RGZ was significantly prevented in the absence of external $\mathrm{Ca}^{2+}$ (Fig. $3 \mathrm{C}$ ). These results, summarized in the Fig. 3D, suggest that the main component of the $\mathrm{Ca}^{2+}$ signal elicited by RGZ was represented by the $\mathrm{Ca}^{2+}$ entry across the plasma membrane while RGZ seemed to be not able to release $\mathrm{Ca}^{2+}$ from internal stores.

\section{RGZ increases intracellular [ $\left.\mathrm{Ca}^{2+}\right]$ via TRP channels activation}

We next sought to identify the entry pathway responsible for the $\mathrm{Ca}^{2+}$ influx triggered by RGZ. When extracellular $\mathrm{Ca}^{2+}$ was removed, the inhibition of sarcoendoplasmic reticulum $\mathrm{Ca}^{2+}$ $\mathrm{Mg}^{2+}$ ATPase (SERCA) with $20 \mu \mathrm{M}$ Cyclopiazonic acid (CPA), evoked a transient cytosolic $\mathrm{Ca}^{2+}$ increase (Fig. 4A). Restoration of extracellular $\left[\mathrm{Ca}^{2+}\right]$ to $1.0 \mathrm{mM}$ in the continuous presence of CPA evoked a second cytosolic $\left[\mathrm{Ca}^{2+}\right]$ increase of similar magnitude. The latter increase in cytosolic $\left[\mathrm{Ca}^{2+}\right]$ represents the $\mathrm{Ca}^{2+}$-entry incurred mostly as a result of store depletion by CPA indeed mediated by the store-operated channels (SOCs). Interestingly, exposure of MCD4 cells to RGZ did not affect the $\mathrm{Ca}^{2+}$ increase evoked by CPA in the absence of extracellular $\mathrm{Ca}^{2+}$, 
A

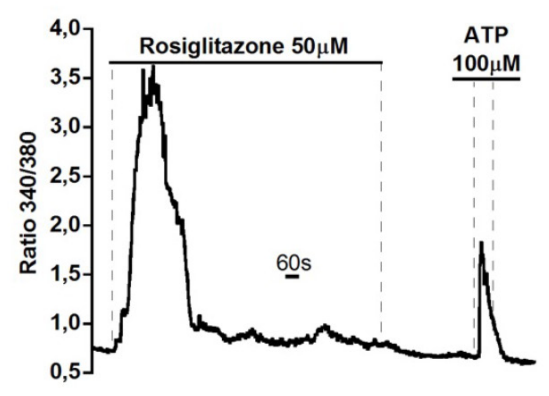

C

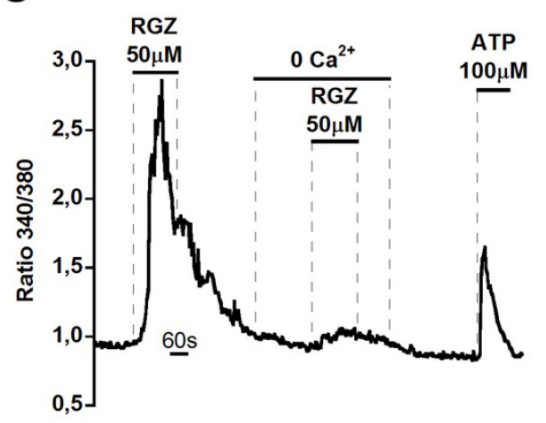

B

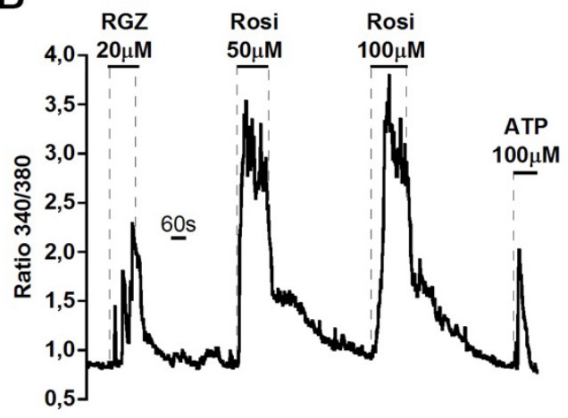

D

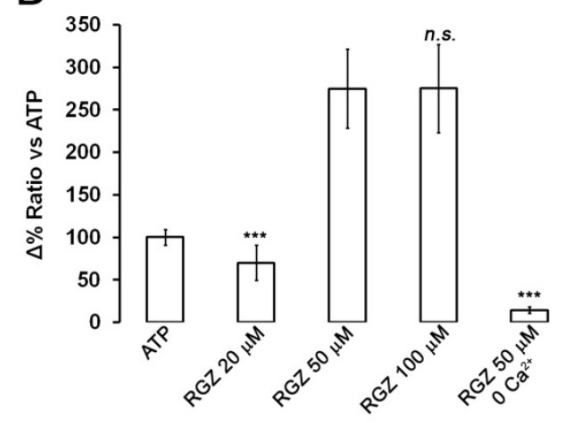

Fig. 3. RGZ increases intracellular $\left[\mathrm{Ca}^{2+}\right]$ as measured in Fura-2-loaded MCD4 cells. (A) RGZ (20 min, $50 \mu \mathrm{M}$, $\mathrm{n}=5)$ transiently increased intracellular $\mathrm{Ca}^{2+}$ level $(278.29 \% \pm 29.60, \mathrm{n}=5,73$ cells, $\mathrm{P}<0.001)$ when compared with the $\mathrm{Ca}^{2+}$-mobilizing agonist ATP $(100 \mu \mathrm{M})$ used in all the experiments performed as internal control. (B) Increasing doses of RGZ ( $3 \mathrm{~min}, 20,50$ and $100 \mu \mathrm{M}, \mathrm{n}=4,49$ cells) elevated intracellular $\mathrm{Ca}^{2+}$ of about $69.89 \% \pm 20.62,274.68 \% \pm 46.52,274.88 \% \pm 51.80$, respectively. (C) RGZ-induced increase in intracellular $\mathrm{Ca}^{2+}$ was significantly reduced in the absence of extracellular $\mathrm{Ca}^{2+}(288.49 \% \pm 50,14$ vs $14.43 \% \pm 3.48, \mathrm{n}=4,41$ cells). (D) Summary of data. ${ }^{* * *}$ P $<0.001$ vs RGZ $50 \mu$ M; n.s. P > 0.05 vs RGZ $50 \mu$ M.

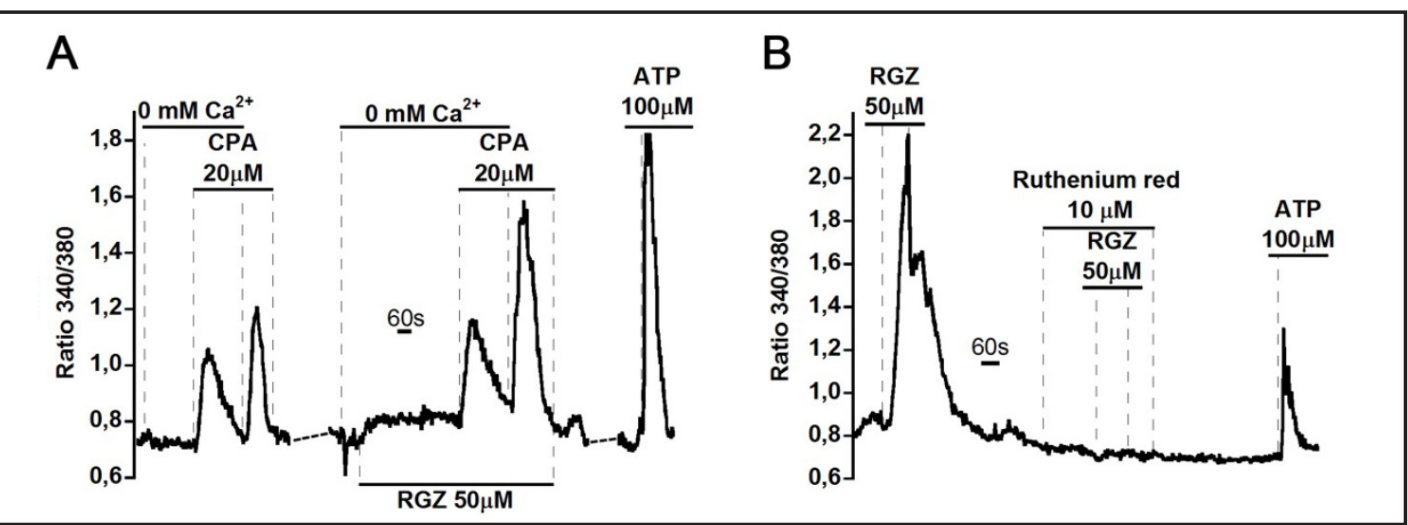

Fig. 4. RGZ activates $\mathrm{Ca}^{2+}$ channels at the plasma membrane as measured in Fura-2-loaded MCD4 cells. (A) CPA $(20 \mu \mathrm{M})$-induced store emptying in a free $\mathrm{Ca}^{2+}$ extracellular solution was unaffected by 20 min pretreatment with RGZ $50 \mu \mathrm{M}(31.19 \% \pm 5.4$ vs $33.95 \% \pm 7.5, \mathrm{n}=5,60$ cells $)$. On the other hand, re-addition of extracellular $\mathrm{Ca}^{2+}$ in the continuous presence of CPA elicited a $\mathrm{Ca}^{2+}$ entry that was significantly increased after 20 min pretreatment wit RGZ $50 \mu \mathrm{M}(41.28 \% \pm 2.5$ vs $67.89 \% \pm 4.3, \mathrm{n}=5,60$ cells, $\mathrm{P}<0.01)(\mathrm{B}) \mathrm{RGZ}$-induced increase in intracellular $\mathrm{Ca}^{2+}$ was completely abolished after 10 min pretreatment with $10 \mu \mathrm{M}$ ruthenium red $10 \mu \mathrm{M}(262.05 \% \pm 30,4$ vs $5.08 \% \pm 1.57, \mathrm{n}=4,44$ cells, $\mathrm{P}<0.001)$.

while $\mathrm{Ca}^{2+}$ entry elicited in presence of $1.0 \mathrm{mM}$ extracellular $\mathrm{Ca}^{2+}$ was significantly increased by RGZ 50 $\mathrm{MM}$ (Fig. 4A). These results suggest that the RGZ-induced increase of intracellular $\mathrm{Ca}^{2+}$ is not due to inhibition of the SERCA pump, as previously reported in monocytes cells 
Fig. 5. Expression of TRP channels in MCD4 cells by RT-PCR analysis. Total RNA from MCD4 and mouse kidney was probed for the presence of mRNA coding TRP channels. Strong signals for TRPC3, TRPC6, TRPM3, TRPP2, TRPV4 and TRPV6 were detected and reported while the presence of mRNA for TRPV5 was not detected in MCD4 cells. Control RT-PCR was performed using primers amplifying mouse $\beta$-actin (not shown). The TRP amplimers obtained from MCD4 cells were the same size as those obtained using mouse kidney cDNA as PCR template.

[32], rather suggesting the activation of $\mathrm{Ca}^{2+}$ channels at the plasma membrane.

Because several TRP channels are expressed in the collecting duct cells, where MCD4 cells derive from [33], we examined the possible contribution of these pathways for $\mathrm{Ca}^{2+}$ influx in the RGZ-induced cytosolic $\mathrm{Ca}^{2+}$ increase. Here, pretreatment with the nonspecific TRP channels blocker ruthenium red (RR, $10 \mu \mathrm{M})$ completely abolished RGZinduced increase in Fura-2 fluorescence ratio (Fig. 4B). These data indicate that a

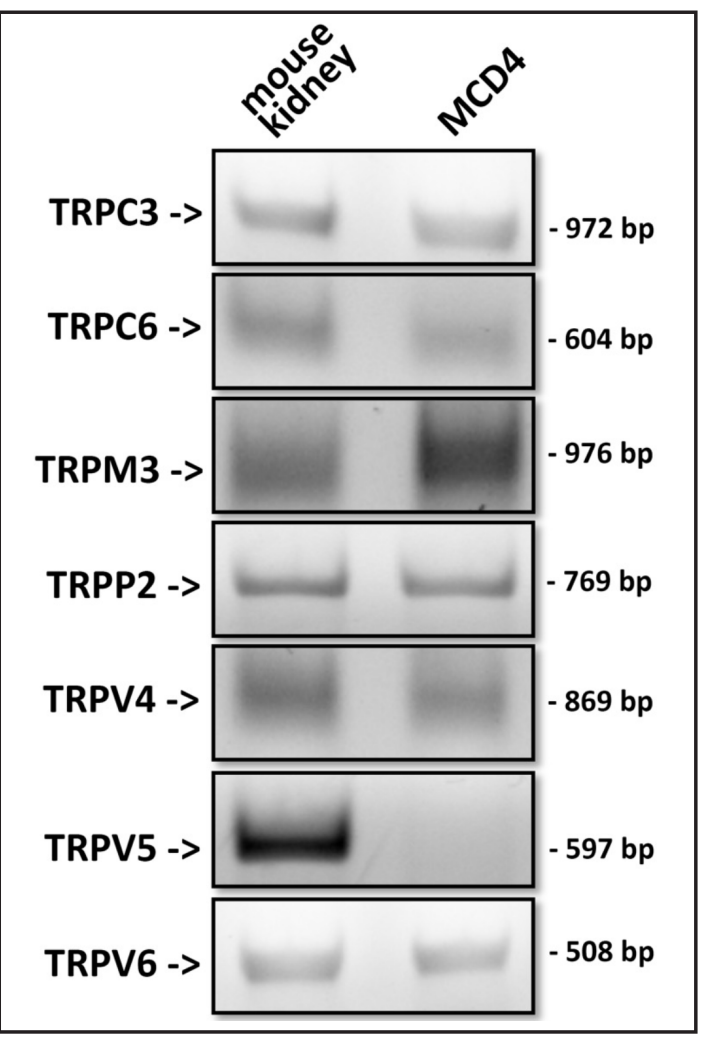
TRP channel-dependent $\mathrm{Ca}^{2+}$ entry pathway is involved in the RGZ-induced intracellular $\mathrm{Ca}^{2+}$ increase.

RT-PCR studies were carried out to evaluate the expression of TRP channels in cultured MCD4 cells. The RT-PCR experiments were performed on total RNA extracted from confluent MCD4 cells and mouse kidney as positive control (see Table 1 for primers used in the reactions). As showed in Fig. 5, MCD4 cells were found to express TRPC3, TRPC6, TRPM3, TRPP2, TRPV4 and TRPV6 transcripts. TRPV5 transcript was the only TRP channel undetectable in MCD4 cells.

Therefore, we investigated the possible involvement of each isoform of TRP channels expressed in MCD4 cells in inducing $\mathrm{Ca}^{2+}$ increase upon exposure to RGZ. At first, perfusion with RGZ $50 \mu \mathrm{M}$ did not alter Fura-2 fluorescence ratio in wild type HEK293 cells, previously reported to express functional TRPC 3 and TRPC 6 channels [34-37], suggesting that these two channels are likely not involved in the RGZ-induced $\mathrm{Ca}^{2+}$ increase observed in MCD4 (Fig. $6 \mathrm{~A})$.

We thus explored the possibility that the $\mathrm{Ca}^{2+}$-permeable TRPV4 channel, a critical determinant of mechanosensitive properties in distal nephron cells [38, 39], might represent the $\mathrm{Ca}^{2+}$ entry pathway elicited by RGZ. However, 10 min pretreatment with the TRPV4 selective inhibitor RN 1734 [40] $(10 \mu \mathrm{M})$ did not significantly reduce the RGZ induced $\mathrm{Ca}^{2+}$ increase measured in Fura 2-loaded cells (Fig. 6B). Same results were obtained with higher concentrations of RN 1734 ( 20 and $50 \mu \mathrm{M}$, data not shown). These data indicate that TRPV4 is not involved in the RGZ induced $\mathrm{Ca}^{2+}$ increase.

Therefore, we investigated the possible role of TRPV6 in the $\mathrm{Ca}^{2+}$-mediated response elicited by RGZ. Unfortunately, there is no selective blocker for TRPV6-mediated calcium influx available $[41,42]$, therefore we considered the knockdown approach to uncover the role of TRPV6 in mediating the $\mathrm{Ca}^{2+}$ influx responsible of the AQP2 membrane accumulation. As shown in Fig. 6C (inset) 48h after transfection with siRNA against TRPV6, TRPV6 mRNA was reduced of about $60 \%$ in MCD4 cells, compared to control siRNA, as revealed by semiquantitative RT-PCR. $\mathrm{Ca}^{2+}$ measurements under this experimental conditions indicated that TRPV6 siRNA significantly reduced (of about 65 \%) the RGZ-induced increase in Fura- 
A

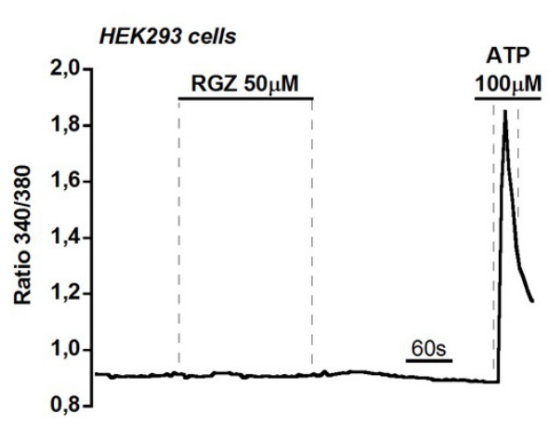

C

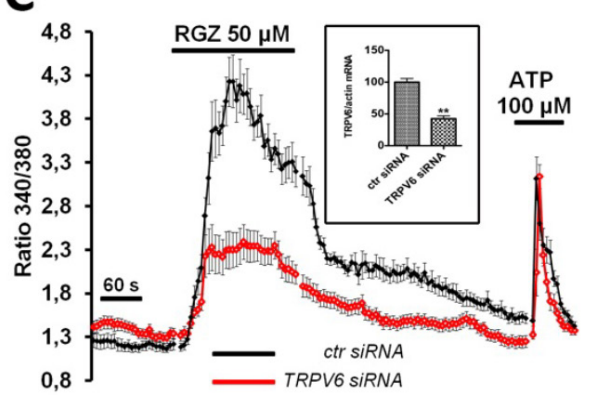

B
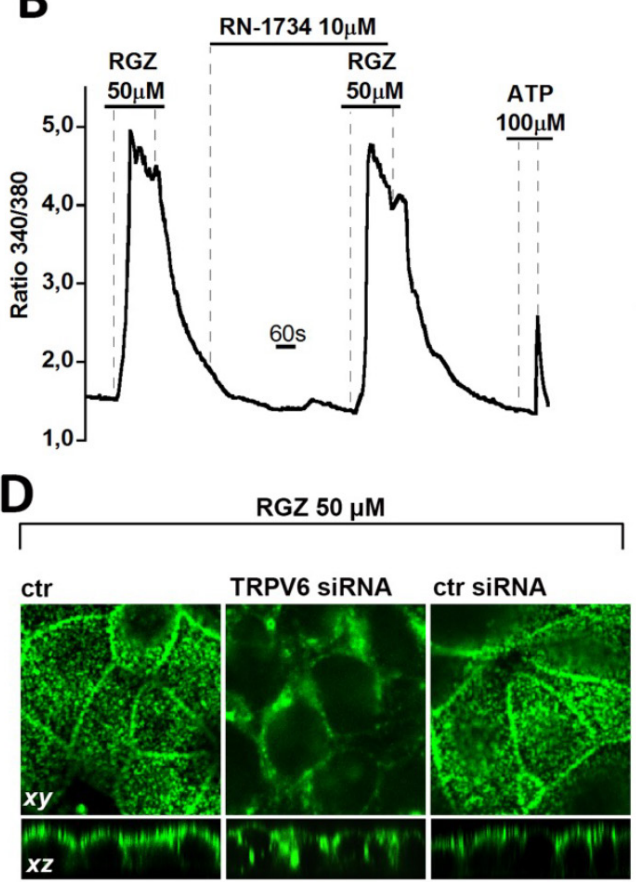

Fig. 6. RGZ increases intracellular $\left[\mathrm{Ca}^{2+}\right]$ via TRPV6 channel activation as measured in Fura-2-loaded MCD4 cells. (A) In Fura-2 loaded-HEK293 cells, RGZ $(50 \mu \mathrm{M}, \mathrm{n}=4)$ did not elicit intracellular $\mathrm{Ca}^{2+}$ changes when compared with the $\mathrm{Ca}^{2+}$-mobilizing agonist ATP; (B) RGZ-induced increase in intracellular $\mathrm{Ca}^{2+}$ was not significantly inhibited by pretreatment with the TRPV4 specific inhibitor RN-1734 $(269.45 \% \pm 42,4$ vs $275.18 \% \pm 41.67, n=4,62$ cells, $p=n . s$.) (C) TRPV6 mRNA was downregulated by specific siRNA (inset). Under this condition the RGZ-induced increase in intracellular $\mathrm{Ca}^{2+}$ measured with respect to those elicited by ATP $(100 \%)$ was significantly reduced (unpaired data, $\mathrm{p}<0.01)$ in TRPV6 siRNA-transfected cells (red line, $83.66 \% \pm 17.39, \mathrm{n}=4,59$ cells) compared to control siRNA-transfected cells (black line, $233.44 \% \pm 13.9, \mathrm{n}=4$, 62 cells). The data plotted are averaged from all the cells acquired for each condition. Data are expressed as mean (squares) $\pm \mathrm{SE}$ (vertical bars). Note that ATP-induced Fura-2 ratio increase was not significantly changed after transfection with TRPV6- or CTR siRNA, respectively ( $\triangle$ Ratio: 1.77 a.u. \pm 0.2 vs 1.94 a.u. \pm 0.2 , p=n.s.). (D) MCD4 cells transfected with the Lipofectamine reagent alone (ctr) or in combination with TRPV6 siRNA or control siRNA were analyzed $48 \mathrm{~h}$ after transfection for AQP2 intracellular localization. Af-

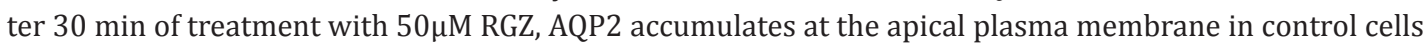
(ctr) and ctr siRNA-transfected cells (ctr siRNA). TRPV6 knockdown completely prevented the RGZ-induced $\mathrm{AQP} 2$ accumulation at the apical plasma membrane. Representative pictures in the $x y$ and $x z$ confocal plans from three independent experiments.

2 fluorescence ratio (Fig. 6C). Importantly, the response to ATP, used as internal control to quantify intracellular $\mathrm{Ca}^{2+}$ changes, was unaffected by transfection with either TRPV6 or control siRNA. In line with this partially blunted $\mathrm{Ca}^{2+}$ response, immunofluorescence localization of AQP2 showed that the RGZ-induced apical accumulation of AQP2 was dramatically inhibited in TRPV6 siRNA-transfected cells but not in ctr siRNA-transfected cells (Fig. 6D).

\section{Discussion}

TZDs, synthetic agonists of PPAR- $\gamma$ are highly beneficial in the treatment of type II diabetes. However, they are also associated with fluid retention and edema $[43,44]$, potentially 
Fig. 7. Proposed schematic diagram illustrating RGZinduced effect on AQP2 apical membrane expression in MCD4 cells. RGZ-induced exposure of AQP2 on the apical membrane of MCD4 cells depends on extracellular calcium influx through TRPV6 (black solid line). TRPV6 could be activated either by direct interaction with RGZ (red dashed line) or after activation of nuclear PPAR- $\gamma$ (green dashed line).

serious side effects, whose origin is still not fully understood. In the last decade many works attempted to demonstrate that RGZ may activate water and sodium reabsorption in the kidney, likely induced by a drop in mean arterial blood pressure (MAP) induced by RGZ. The aim of those studies was to investigate whether $\mathrm{Na}^{+}$transporters and aquaporins, in particular AQP2, might play a significant role in the edema formation.

Song et al. showed that RGZ administration induced reduction of urine volume and

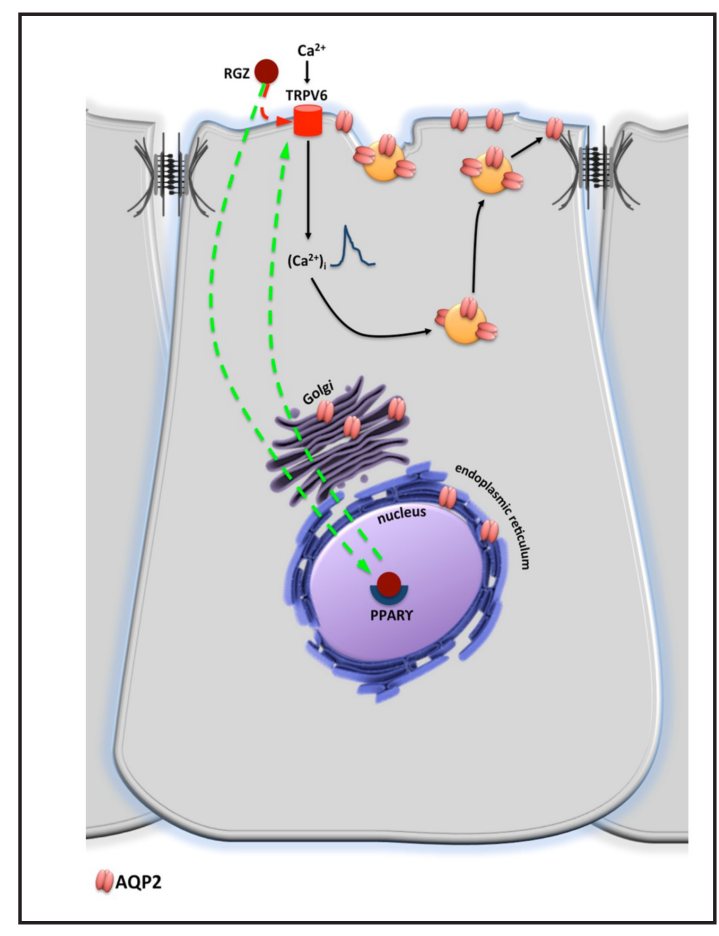
$\mathrm{Na}^{+}$excretion in Sprague-Dawley rats over a period of 3 days [13]. Interestingly, they measured a significant protein upregulation of $\mathrm{Na}^{+}$transporters $\left(\mathrm{Na}^{+}-\mathrm{K}^{+}\right.$-ATPase, NHE3, $\mathrm{Na}^{+}-\mathrm{Pi} 2$ and NKCC2), AQP2 and AQP3 after 3 days of RGZ administration. Later on, Chen et al. showed that also the PPAR- $\gamma$ agonist GI262570 upregulated ENaC, $\mathrm{Na}^{+}-\mathrm{K}^{+}-\mathrm{ATP}$ ase and AQP2 [45]. Interestingly, a time-course analysis of AQP2 abundance at the cell plasma membrane, performed in Sprague-Dawley rats treated with RGZ, showed that AQP2 unglycosylated band was upregulated at day 3of RGZ treatment, followed by return to basal levels at day 5 [23]. This effect observed at the plasma membrane suggests that, besides boosting AQP2 transcription, RGZ might also activate short-term intracellular mechanisms increasing AQP2 abundance at the plasma membrane.

In this work, we hypothesized that if, in one hand, water retention is an undesirable side effect of RGZ therapy, on the other hand, it might be beneficial for those pathological conditions characterized by elevated water excretion in the kidney tubule.

In particular, mutations of the vasopressin type-2 receptor (V2R) severely impair both AQP2-mediated water reabsorption and the NKCC2-mediated solute reabsorption, the latter responsible for the formation of the cortico-medullary solute gradient in the kidney medulla [46]. In fact, both AQP2 and NKCC2 are upregulated in abundance [47-49] and plasma membrane expression $[50,51]$ by AVP. As a consequence of the unpaired AVP signaling, the affected subjects are unable to concentrate their urine even during severe dehydration or after infusion of exogenous AVP and develop a disease known as nephrogenic diabetes insipidus (NDI) characterized by polyuria and hyponatremia[21, 22, 52].

In attempt of uncovering a novel RGZ-sensitive intracellular mechanisms promoting AQP2 exocytosis for possible future clinical applications, we dissected the signal transduction pathways activated by RGZ in cultured renal cells.

We showed that, in MCD 4 cells, $50 \mu \mathrm{M}$ RGZ was as potent as FK in promoting a robust AQP2 accumulation at the apical plasma membrane. We provided also a number of observations that this effect is independent on intracellular cAMP elevations/PKA activation: a) the effect of RGZ on AQP2 trafficking is not prevented by incubation with the PKA inhibitor H89, b) cAMP intracellular concentrations, as measured by FRET-based probes, are unchanged after RGZ treatment, c) RGZ does not increase AQP2 phosphorylation at its PKA consensus site, serine 256 [53]. 
Although AQP2 exocytosis is triggered by PKA-dependent phosphorylation following systemic release of the antidiuretic hormone AVP (antidiuresis), over the last decade a number of papers uncovered a number of phosphorylation-independent mechanisms either occurring under physiological conditions or induced by drugs treatment, leading to significant increase of AQP2 at the apical plasma membrane of CD cells [20, 22, 54-59]. One of the mechanisms responsible for a significant fusion of AQP2-storage vesicles with the apical plasma membrane is an increase of intracellular $\mathrm{Ca}^{2+}$ concentration. In general, in neuronal cells or other specialized secretory cells, regulated exocytosis is facilitated by a burst of intracellular $\mathrm{Ca}^{2+}[60-62]$. As for AQP2, we previously showed that in renal cells the $\mathrm{Ca}^{2+}$-mobilizing agent ATP stimulates per se a robust accumulation of AQP2 at the apical plasma membrane [63].

The evidence that RGZ might impact intracellular $\mathrm{Ca}^{2+}$ homeostasis at different level has been previously reported. Lee and co-workers demonstrated that the decreases of intracellular $\mathrm{Ca}^{2+}$ transients and $\mathrm{Ca}^{2+}$ stores recorded in diabetes and diabetic hypertensive hearts were attenuated by RGZ treatment via enhancement of SERCA2a expression and increased reuptake of intracellular $\mathrm{Ca}^{2+}$ after $\mathrm{Ca}^{2+}$ release in rat ventricular myocytes [64, 65].

In addition, incubation for over 5 min with $20 \mu \mathrm{M}$ RGZ significantly increased basal intracellular $\left[\mathrm{Ca}^{2+}\right]$ levels in isolated peripheral blood monocytes. This increase was not apparent until after $5 \mathrm{~min}$ incubation with RGZ, and levels remained elevated for up to $1 \mathrm{~h}$ post-exposure, probably indicating a $\mathrm{Ca}^{2+}$ leak into the cytoplasm rather than the activation of a $\mathrm{Ca}^{2+}$-mediated signaling cascade [66]. More recently, the mechanism underlying this effect was identified as a dose-dependent inhibition of SERCA2b [32].

In the present study, short time exposure (up to $20 \mathrm{~min}$ ) to RGZ $50 \mu \mathrm{M}$ did not inhibit the activity of the SERCA pump since CPA-induced store emptying, in a $\mathrm{Ca}^{2+}$-free extracellular solution, was not affected by pretreatment with RGZ (Fig. 4A). On the other hand, the fact that the capacitive $\mathrm{Ca}^{2+}$ entry induced by re-addition of extracellular $\mathrm{Ca}^{2+}$ in the presence of CPA was significantly larger in the presence of RGZ, clearly suggested the activation of an additional $\mathrm{Ca}^{2+}$ entry pathway at the plasma membrane.

In line with this hypothesis, the evidence that in our experiments RR, a nonspecific inhibitor of TRP channels completely prevented the RGZ-induced intracellular $\mathrm{Ca}^{2+}$ increase (Fig. 4B) and AQP2 translocation at the apical plasma membrane (data not shown), suggested that activation of these channels might account for this pleiotropic effect of RGZ. A RT-PCT-based screening indicated that multiple members of TRP channels (TRPM3, TRPC6, TRPC3, TRPV4, TRPP2 and TRPV6) are expressed in MCD4 cells (Fig. 5). We next performed a series of experiments to identify whether one or more of the TRP channels were activated by RGZ in renal cells. Majeed and coworkers showed that TRPM3 was potently inhibited by high doses of RGZ (IC ${ }_{50}, 5-10 \mu \mathrm{M}$ ) in HEK 293 cells [67]. We next evaluated the effect of RGZ stimulation on HEK293 cells expressing, together with MCD4 cells, functional TRPC6 and TRPC3. However, RGZ did not evoke significant $\mathrm{Ca}^{2+}$ increases in Fura-2 loaded HEK-293 cells, likely excluding these TRP channels as the putative candidates in the RGZ-induced $\mathrm{Ca}^{2+}$ influx also in renal cells (Fig. 6A).

Another possible candidate responsible for the RGZ-induced $\mathrm{Ca}^{2+}$ influx in our cells was TRPV4. This channel is endogenously expressed in renal CD cells where it displays a mechanosensitive function with activation properties consistent with a molecular sensor of both fluid flow and osmolality $[38,68]$. Hypotonicity does not directly result in channel opening, but rather leads to stimulation of intracellular signaling cascades activating TRPV4 (for a review see [69]). On the other hand, TRPV4 transduces flow-induced mechanical stimuli via a sustained $\mathrm{Ca}^{2+}$ influx in collecting duct cells and other epithelia [69]. Furthermore, TRPV4 might form an apical mechanosensitive complex with TRPP2 localized to the primary cilium of cultured CD cells working as a sensor reporting velocity of the tubular flow [70]. The expression of dominant negative constructs for either TRPV4 or TRPP2 abolished flowinduced $\mathrm{Ca}^{2+}$ influx in M-1 collecting duct cells [71]. However, our results with increasing doses $(10,20$ and $50 \mu \mathrm{M})$ of the specific blocker RN-1734 excluded the involvement of TRPV4 (and likely TRPP2) in the RGZ-induced $\mathrm{Ca}^{2+}$ flux in MCD4 cells (Fig. 6B).

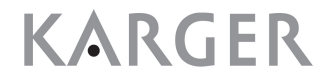


Finally, we evaluated the role of TRPV6 in RGZ-induced $\mathrm{Ca}^{2+}$ influx. TRPV6, a highly selective $\mathrm{Ca}^{2+}$ channel [72], is expressed in distal renal tubules [73]. Interestingly, its localization at the apical domain of principal and intercalated cells of the $C D$, which are not generally implicated in active $\mathrm{Ca}^{2+}$ reabsorption, suggests a physiological role that has not yet been clarified because to the lack of selective blockers for TRPV6-mediated $\mathrm{Ca}^{2+}$ influx. $[41,42]$. In our experiments (Fig. 6, C), we found that TRPV6 silencing by siRNA, significantly inhibits (of about 65\%) the RGZ-induced $\mathrm{Ca}^{2+}$ influx and, in parallel, dramatically blunted the RGZ-induced accumulation of AQP2 at the apical plasma membrane in MCD4 cells (Fig. 6D).

Taken together, the results obtained in this study indicate that in MCD4 cells RGZ activates a $\mathrm{Ca}^{2+}$ influx, likely mediated by TRPV6, responsible for increased AQP2 exocytosis at the apical plasma membrane. The schematic diagram in Fig. 7 illustrates the supposed mechanism of action elicited by short-term exposure to RGZ in MCD4 cells. Here, we cannot discriminate whether or not rosiglitazone activates TRPV6 channels with a mechanism that involves PPAR- $\gamma$. We can only speculate that, according to the fact that RGZ-induced $\mathrm{Ca}^{2+}$ increase is extremely fast, RGZ directly interacts with TRPV6. Indeed, RGZ has been proved to directly affect several types of ion channels [74-76]. Importantly, RGZ inhibits TRPM3 and activates TRPC5 channels expressed in HEK 293 cells with a mechanism that does not involve PPAR- $\gamma$ activation but rather a direct interaction with drug binding sites on the channels. On the other hand, there is only one evidence that long-term treatment with TZD affects voltage-gated $\mathrm{Ca}^{2+}$ currents in cultured hippocampal neurons via direct activation of PPAR- $\gamma[77]$.

Overall, RGZ-induced activation of TRPV6 might be responsible for the increased AQP2 plasma membrane expression observed in vivo in animals treated with RGZ [23].

Of note we observed that also Pioglitazone, another member of the TZDs family, induces a comparable effect on both AQP2 trafficking and $\mathrm{Ca}^{2+}$ signaling in the same cellular model (data not shown).

In conclusion, these results are of great physiological importance as they uncover an additional vasopressin-independent mechanism responsible for AQP2 plasma membrane expression in renal cells.

The therapeutic implication of this evidence is that members of the TZDs family might be useful to increase AQP2 membrane expression in pathological states caused by impairment of AVP signal transduction. We are aware that the doses of RGZ used in this study are higher than those prescribed to patients and this might explain why, no one has demonstrated a short-term antidiuretic effect of RGZ in animals or humans. Moreover, TZDs are often prescribed along with diuretics to lower blood pressure, which might mask the possible antidiuretic effect of TZDs. Further experimentation on animal models will help to demonstrate the efficacy of TZDs on AQP2 trafficking in vivo.

\section{Acknowledgments}

This work was supported by funding from the Italian Ministero della Salute/Italian Drug Agency (project \# MRAR08P011) and by the Fondazione Telethon (project \# GGP12040) to M.S..

\section{Disclosure Statement}

None to declare.

\section{References}

1 Day C: Thiazolidinediones: a new class of antidiabetic drugs. Diabet Med 1999;16:179-192.

2 Fuchtenbusch M, Standl E, Schatz H: Clinical efficacy of new thiazolidinediones and glinides in the treatment of type 2 diabetes mellitus. Exp Clin Endocrinol Diabetes 2000;108:151-163.

- 3 Cariou B, Charbonnel B, Staels B: Thiazolidinediones and PPARgamma agonists: time for a reassessment. Trends Endocrinol Metab 2012;23:205-215. 
4 Jain AK, Vaidya A, Ravichandran V, Kashaw SK, Agrawal RK: Recent developments and biological activities of thiazolidinone derivatives: a review. Bioorg Med Chem 2012;20:3378-3395.

Kung J, Henry RR: Thiazolidinedione safety. Expert Opin Drug Saf 2012;11:565-579.

6 Beltowski J, Rachanczyk J, Wlodarczyk M: Thiazolidinedione-induced fluid retention: recent insights into the molecular mechanisms. PPAR Res 2013;2013:628628.

7 Patel C, Wyne KL, McGuire DK: Thiazolidinediones, peripheral oedema and congestive heart failure: what is the evidence? Diab Vasc Dis Res 2005;2:61-66.

$>8$ Yang T: Kidney-specific gene targeting: insight into thiazolidinedione-induced fluid retention. Nephrology (Carlton) 2006;11:201-206.

-9 Jia Z, Sun Y, Yang G, Zhang A, Huang S, Heiney KM, Zhang Y: New Insights into the PPAR gamma Agonists for the Treatment of Diabetic Nephropathy. PPAR Res 2014;2014:818530.

10 Guan Y, Zhang Y, Davis L, Breyer MD: Expression of peroxisome proliferator-activated receptors in urinary tract of rabbits and humans. Am J Physiol 1997;273:F1013-1022.

11 Hong G, Lockhart A, Davis B, Rahmoune H, Baker S, Ye L, Thompson P, Shou Y, O'Shaughnessy K, Ronco P, Brown J: PPARgamma activation enhances cell surface ENaCalpha via up-regulation of SGK1 in human collecting duct cells. FASEB J 2003;17:1966-1968.

12 Yang T, Michele DE, Park J, Smart AM, Lin Z, Brosius FC, 3rd, Schnermann JB, Briggs JP: Expression of peroxisomal proliferator-activated receptors and retinoid $\mathrm{X}$ receptors in the kidney. Am J Physiol 1999;277:F966-973.

13 Song J, Knepper MA, Hu X, Verbalis JG, Ecelbarger CA: Rosiglitazone activates renal sodium- and waterreabsorptive pathways and lowers blood pressure in normal rats. J Pharmacol Exp Ther 2004;308:426433.

14 Zhang H, Zhang A, Kohan DE, Nelson RD, Gonzalez FJ, Yang T: Collecting duct-specific deletion of peroxisome proliferator-activated receptor gamma blocks thiazolidinedione-induced fluid retention. Proc Natl Acad Sci USA 2005;102:9406-9411.

15 Vallon V, Hummler E, Rieg T, Pochynyuk O, Bugaj V, Schroth J, Dechenes G, Rossier B, Cunard R, Stockand J: Thiazolidinedione-induced fluid retention is independent of collecting duct alphaENaC activity. J Am Soc Nephrol 2009;20:721-729.

16 Nielsen S, Frokiaer J, Marples D, Kwon TH, Agre P, Knepper MA: Aquaporins in the kidney: from molecules to medicine. Physiol Rev2002;82:205-244.

17 Tamma G, Procino G, Svelto M, Valenti G: Cell culture models and animal models for studying the pathophysiological role of renal aquaporins. Cellular and molecular life sciences : CMLS 2012;69:1931-1946.

18 Valenti G, Procino G, Tamma G, Carmosino M, Svelto M: Minireview: aquaporin 2 trafficking. Endocrinology 2005;146:5063-5070.

19 Nielsen S, Chou CL, Marples D, Christensen EI, Kishore BK, Knepper MA: Vasopressin increases water permeability of kidney collecting duct by inducing translocation of aquaporin-CD water channels to plasma membrane. Proc Nat Acad Scie USA 1995;92:1013-1017.

20 Bouley R, Hasler U, Lu HA, Nunes P, Brown D: Bypassing vasopressin receptor signaling pathways in nephrogenic diabetes insipidus. Seminars Nephrol 2008;28:266-278.

21 Wesche D, Deen PM, Knoers NV: Congenital nephrogenic diabetes insipidus: the current state of affairs. Pediatr Nephrol 2012;27:2183-2204.

22 Moeller HB, Rittig S, Fenton RA: Nephrogenic diabetes insipidus: essential insights into the molecular background and potential therapies for treatment. Endocr Rev 2013;34:278-301.

23 Tiwari S, Blasi ER, Heyen JR, McHarg AD, Ecelbarger CM: Time course of AQP-2 and ENaC regulation in the kidney in response to PPAR agonists associated with marked edema in rats. Pharmacol Res 2008;57:383392.

24 Procino G, Barbieri C, Tamma G, De Benedictis L, Pessin JE, Svelto M, Valenti G: AQP2 exocytosis in the renal collecting duct -- involvement of SNARE isoforms and the regulatory role of Munc18b. J Cell Sci 2008;121:2097-2106.

25 Tamma G, Procino G, Strafino A, Bononi E, Meyer G, Paulmichl M, Formoso V, Svelto M, Valenti G: Hypotonicity induces aquaporin-2 internalization and cytosol-to-membrane translocation of ICln in renal cells. Endocrinology 2007;148:1118-1130.

26 Christensen BM, Zelenina M, Aperia A, Nielsen S: Localization and regulation of PKA-phosphorylated AQP2 in response to V(2)-receptor agonist/antagonist treatment. Am J Physiol Renal Physiol 2000;278:F29-42.

27 Stoos BA, Naray-Fejes-Toth A, Carretero OA, Ito S, Fejes-Toth G: Characterization of a mouse cortical collecting duct cell line. Kidney Int 1991;39:1168-1175.

-28 Iolascon A, Aglio V, Tamma G, D'Apolito M, Addabbo F, Procino G, Simonetti MC, Montini G, Gesualdo L, Debler EW, Svelto M, Valenti G: Characterization of two novel missense mutations in the AQP2 gene causing nephrogenic diabetes insipidus. Nephron Physiol 2007;105:33-41. 
-29 Post SR, Rump LC, Zambon A, Hughes RJ, Buda MD, Jacobson JP, Kao CC, Insel PA: ATP activates cAMP production via multiple purinergic receptors in MDCK-D1 epithelial cells. Blockade of an autocrine/ paracrine pathway to define receptor preference of an agonist. J Biol Chem 1998;273:23093-23097.

30 Deen PM, Rijss JP, Mulders SM, Errington RJ, van Baal J, van Os CH: Aquaporin-2 transfection of MadinDarby canine kidney cells reconstitutes vasopressin-regulated transcellular osmotic water transport. J Am Soc Nephrol 1997;8:1493-1501.

-31 van der Krogt GN, Ogink J, Ponsioen B, Jalink K: A comparison of donor-acceptor pairs for genetically encoded FRET sensors: application to the Epac cAMP sensor as an example. PLoS One 2008;3:e1916.

-32 Caddy J, Singh N, Atkin L, Ahluwalia M, Roberts A, Lang D, Thomas AW, Webb R: Rosiglitazone transiently disturbs calcium homeostasis in monocytic cells. Biochem Biophys Res Commun 2008;366:149-155.

-33 Woudenberg-Vrenken TE, Bindels RJ, Hoenderop JG: The role of transient receptor potential channels in kidney disease. Nat Rev Nephrol 2009;5:441-449.

34 Garcia RL, Schilling WP: Differential expression of mammalian TRP homologues across tissues and cell lines. Biochem Biophys Res Commun 1997;239:279-283.

-35 Groschner K, Hingel S, Lintschinger B, Balzer M, Romanin C, Zhu X, Schreibmayer W: Trp proteins form store-operated cation channels in human vascular endothelial cells. FEBS Lett 1998;437:101-106.

-36 Wu X, Babnigg G, Zagranichnaya T, Villereal ML: The role of endogenous human Trp4 in regulating carbachol-induced calcium oscillations in HEK-293 cells. J Biol Chem 2002;277:13597-13608.

37 Bugaj V, Alexeenko V, Zubov A, Glushankova L, Nikolaev A, Wang Z, Kaznacheyeva E, Bezprozvanny I, Mozhayeva GN: Functional properties of endogenous receptor- and store-operated calcium influx channels in HEK293 cells. J Biol Chem 2005;280:16790-16797.

-38 Wu L, Gao X, Brown RC, Heller S, O'Neil RG: Dual role of the TRPV4 channel as a sensor of flow and osmolality in renal epithelial cells. Am J Physiol Renal Physiol 2007;293:F1699-1713.

-39 Berrout J, Jin M, Mamenko M, Zaika O, Pochynyuk O, O'Neil RG: Function of transient receptor potential cation channel subfamily V member 4 (TRPV4) as a mechanical transducer in flow-sensitive segments of renal collecting duct system. J Biol Chem 2012;287:8782-8791.

40 Vriens J, Appendino G, Nilius B: Pharmacology of vanilloid transient receptor potential cation channels. Mol Pharmacol 2009; 75:1262-1279.

41 Bolanz KA, Hediger MA, Landowski CP: The role of TRPV6 in breast carcinogenesis. Mol Cancer Ther 2008;7:271-279.

-42 Bolanz KA, Kovacs GG, Landowski CP, Hediger MA: Tamoxifen inhibits TRPV6 activity via estrogen receptor-independent pathways in TRPV6-expressing MCF-7 breast cancer cells. Mol Cancer Res 2009; 7:2000-2010.

43 Wang F, Aleksunes LM, Reagan LA, Vergara CM: Management of rosiglitazone-induced edema: two case reports and a review of the literature. Diabetes Technol Ther 2002;4:505-514.

44 Mudaliar S, Chang AR, Henry RR: Thiazolidinediones, peripheral edema, and type 2 diabetes: incidence, pathophysiology, and clinical implications. Endocr Pract 2003;9:406-416.

45 Chen L, Yang B, McNulty JA, Clifton LG, Binz JG, Grimes AM, Strum JC, Harrington WW, Chen Z, Balon TW, Stimpson SA, Brown KK: GI262570, a peroxisome proliferator-activated receptor \{gamma\} agonist, changes electrolytes and water reabsorption from the distal nephron in rats. J Pharmacol Exp Ther 2005;312:718-725.

46 Knepper MA, Kim GH, Fernandez-Llama P, Ecelbarger CA: Regulation of thick ascending limb transport by vasopressin. J Am Soc Nephrol 1999;10:628-634.

47 Kim GH, Ecelbarger CA, Mitchell C, Packer RK, Wade JB, Knepper MA: Vasopressin increases Na-K-2Cl cotransporter expression in thick ascending limb of Henle's loop. Am J Physiol 1999;276:F96-F103.

-48 Hozawa S, Holtzman EJ, Ausiello DA: cAMP motifs regulating transcription in the aquaporin 2 gene. Am J Physiol 1996;270:C1695-1702.

-49 Matsumura Y, Uchida S, Rai T, Sasaki S, Marumo F: Transcriptional regulation of aquaporin-2 water channel gene by cAMP. J Am Soc Nephrol 1997;8:861-867.

50 Rieg T, Tang T, Uchida S, Hammond HK, Fenton RA, Vallon V: Adenylyl cyclase 6 enhances NKCC2 expression and mediates vasopressin-induced phosphorylation of NKCC2 and NCC. Am J Pathol 2013;182:96-106.

51 Fushimi K, Sasaki S, Marumo F: Phosphorylation of serine 256 is required for cAMP-dependent regulatory exocytosis of the aquaporin-2 water channel. J Biol Chem 1997;272:14800-14804.

52 Kortenoeven ML, Fenton RA: Renal aquaporins and water balance disorders. Biochim Biophys Acta 2013;10.1016/j.bbagen.2013.12.002

-53 Nishimoto G, Zelenina M, Li D, Yasui M, Aperia A, Nielsen S, Nairn AC: Arginine vasopressin stimulates phosphorylation of aquaporin-2 in rat renal tissue. Am J Physiol 1999;276:F254-259.

54 Bouley R, Pastor-Soler N, Cohen O, McLaughlin M, Breton S, Brown D: Stimulation of AQP2 membrane 
insertion in renal epithelial cells in vitro and in vivo by the cGMP phosphodiesterase inhibitor sildenafil citrate (Viagra). Am J Physiol Renal Physiol 2005;288:F1103-1112.

55 Li W, Zhang Y, Bouley R, Chen Y, Matsuzaki T, Nunes P, Hasler U, Brown D, Lu HA: Simvastatin enhances aquaporin-2 surface expression and urinary concentration in vasopressin-deficient Brattleboro rats through modulation of Rho GTPase. Am J Physiol Renal Physiol 2011;301:F309-318.

-56 Olesen ET, Rutzler MR, Moeller HB, Praetorius HA, Fenton RA: Vasopressin-independent targeting of aquaporin-2 by selective E-prostanoid receptor agonists alleviates nephrogenic diabetes insipidus. Proc Nat Acad Sci USA 2011;108:12949-12954.

57 Procino G, Barbieri C, Carmosino M, Rizzo F, Valenti G, Svelto M: Lovastatin-induced cholesterol depletion affects both apical sorting and endocytosis of aquaporin-2 in renal cells. Am J Physiol Renal Physiol 2010;298:F266-278.

58 Procino G, Barbieri C, Carmosino M, Tamma G, Milano S, De Benedictis L, Mola MG, Lazo-Fernandez Y, Valenti G, Svelto M: Fluvastatin modulates renal water reabsorption in vivo through increased AQP2 availability at the apical plasma membrane of collecting duct cells. Pflugers Arch 2011;462:753-766.

-59 Procino G, Milano S, Carmosino M, Barbieri C, Nicoletti MC, J HL, Wess J, Svelto M: Combination of secretin and fluvastatin ameliorates the polyuria associated with X-linked nephrogenic diabetes insipidus in mice. Kidney Int 2014;10.1038/ki.2014.10

60 Burgoyne RD, Barclay JW, Ciufo LF, Graham ME, Handley MT, Morgan A: The functions of Munc18-1 in regulated exocytosis. Ann N Y Acad Sci 2009;1152:76-86.

61 Jolly C, Sattentau QJ: Regulated secretion from CD4+ T cells. Trends Immunol 2007;28:474-481.

$\checkmark 62$ Lacy P, Stow JL: Cytokine release from innate immune cells: association with diverse membrane trafficking pathways. Blood 2011;118:9-18.

63 Procino G, Mastrofrancesco L, Tamma G, Lasorsa DR, Ranieri M, Stringini G, Emma F, Svelto M, Valenti G: Calcium-sensing receptor and aquaporin 2 interplay in hypercalciuria-associated renal concentrating defect in humans. An in vivo and in vitro study. PLoS One 2012;7:e33145.

64 Lee TI, Chen YC, Kao YH, Hsiao FC, Lin YK, Chen YJ: Rosiglitazone induces arrhythmogenesis in diabetic hypertensive rats with calcium handling alteration. Int J Cardiol 2013;165:299-307.

65 Shah RD, Gonzales F, Golez E, Augustin D, Caudillo S, Abbott A, Morello J, McDonough PM, Paolini PJ, Shubeita HE: The antidiabetic agent rosiglitazone upregulates SERCA2 and enhances TNF-alpha- and LPS-induced NF-kappaB-dependent transcription and TNF-alpha-induced IL-6 secretion in ventricular myocytes. Cell Physiol Biochem 2005;15:41-50.

66 Singh N, Webb R, Adams R, Evans SA, Al-Mosawi A, Evans M, Roberts AW, Thomas AW: The PPAR-gamma activator, Rosiglitazone, inhibits actin polymerisation in monocytes: involvement of Akt and intracellular calcium. Biochem Biophys Res Commun 2005;333:455-462.

67 Majeed Y, Bahnasi Y, Seymour VA, Wilson LA, Milligan CJ, Agarwal AK, Sukumar P, Naylor J, Beech DJ: Rapid and contrasting effects of rosiglitazone on transient receptor potential TRPM3 and TRPC5 channels. Mol Pharmacol 2011;79:1023-1030.

68 Galizia L, Pizzoni A, Fernandez J, Rivarola V, Capurro C, Ford P: Functional interaction between AQP2 and TRPV4 in renal cells. J Cell Biochem 2012;113:580-589.

69 Pochynyuk 0, Zaika O, O'Neil RG, Mamenko M: Novel insights into TRPV4 function in the kidney. Pflugers Arch 2013;465:177-186.

70 Praetorius HA, Spring KR: A physiological view of the primary cilium. Annu Rev Physiol 2005;67:515-529.

71 Du J, Wong WY, Sun L, Huang Y, Yao X: Protein kinase G inhibits flow-induced Ca2+ entry into collecting duct cells. J Am Soc Nephrol 2012;23:1172-1180.

72 Hoenderop JG, Bindels RJ: Calciotropic and magnesiotropic TRP channels. Physiology (Bethesda) 2008;23:32-40.

73 Nijenhuis T, Hoenderop JG, van der Kemp AW, Bindels RJ: Localization and regulation of the epithelial Ca2+ channel TRPV6 in the kidney. J Am Soc Nephrol 2003;14:2731-2740.

74 Ahn HS, Kim SE, Jang HJ, Kim MJ, Rhie DJ, Yoon SH, Jo YH, Kim MS, Sung KW, Kim SY, Hahn SJ: Open channel block of Kv1.3 by rosiglitazone and troglitazone: Kv1.3 as the pharmacological target for rosiglitazone. Naunyn Schmiedebergs Arch Pharmacol 2007;374:305-309.

75 Lu L, Reiter MJ, Xu Y, Chicco A, Greyson CR, Schwartz GG: Thiazolidinedione drugs block cardiac KATP channels and may increase propensity for ischaemic ventricular fibrillation in pigs. Diabetologia 2008;51:675-685.

76 Jeong I, Choi BH, Hahn SJ: Rosiglitazone inhibits Kv4.3 potassium channels by open-channel block and acceleration of closed-state inactivation. Br J Pharmacol 2011;163:510-520.

77 Pancani T, Phelps JT, Searcy JL, Kilgore MW, Chen KC, Porter NM, Thibault O: Distinct modulation of voltagegated and ligand-gated Ca2+ currents by PPAR-gamma agonists in cultured hippocampal neurons. J Neurochem 2009;109:1800-1811. 